Doi: 10.47650/pjphsr.v1i2.242

ISSN (Online): 2777-1296

OJS: http://journal.unpacti.ac.id/index.php/pjphsr

\title{
SYSTEMATIC REVIEW: ISOMETRIC HANDGRIP EXERCISE IN ELDERLY WITH HYPERTENSION
}

Sistematik Review: Latihan Isometric Handgrip (IHE) pada Lanjut Usia (Lansia) dengan Hipertensi

\author{
Enisah Enisah, Diah Ernawati, Dian Hendrawati, Dian Rahayu, Evi Rachmawati, Femy Novintari, \\ Gira Lugina, Hima Rismawati, Lina Melianawati, Minarti Minarti, Risca Arief, Singgih Arfian, \\ Suparji Suparji, Yayah Zakiyah \\ Program Studi Ners Sekolah Tinggi Ilmu Keperawatan PPNI Jawa Barat
}

*Alamat Korespondensi: bundazahraheaven@gmail.com

\begin{tabular}{l}
\hline Article Info \\
\hline Article History \\
Received: 10 Juli 2021 \\
Revised : 13 Juli 2021 \\
Accepted : 18 Juli 2021
\end{tabular}

\section{Keywords :}

CASP, elderly, hypertension, isometric handgrip, PICOT

\begin{abstract}
ABSTRAK
This study aims to systematic review on the effect of isometric handgrip exercise (IHE) on elderly with hypertension and can be applied as evidence-based practice (EBP) at the Panti Wredha Muhammadiyah Rancabolang, Bandung City. The research method uses the CASP which consists of 11 lists of questions. Formulation of clinical questions using the PICOT format. The results obtained as much as 4 research evidence, 2 evidence have a level of evidence 2 because it used a RCT study design. The other 2 have a level of evidence 3 because they used a quasi experimental study design. Elderly with hypertension can routinely do IHE at the Panti. This is done as an effort to control hypertension and a joint schedule is needed. The advantages of IHE in a short period of time continuously for 2 minutes can cause blood pressure and heart rate to reach stable conditions, no risk of injury, and the technique is quite easy. IHE can be done anywhere, only requires simple tools such as using a ball-shaped tool with a elastic consistency so that elderly with hypertension can press it. IHE can be done without tools, making it easier for elderly with hypertension to do the IHE.
\end{abstract}

Tujuan systematic review ini untuk mengetahui pengaruh isometric handgrip exercise (IHE) pada lanjuat usia yang mengalami hipertensi agar dapat diaplikasikan sebagai evidence-based practice (EBP) pada lansia dengan hipertensi di Panti Wredha Muhammadiyah Rancabolang, Kota Bandung. Metode penelitian menggunakan Critical Appraisal Skills Programme (CASP) Systematic Review yang terdiri dari 11 daftar pertanyaan. Pembuatan rumusan pertanyaan klinis menggunakan format PICOT. Hasil systematic review diperoleh sebanyak 4 bukti penelitian, dengan 2 bukti memiliki level of evidence 2 karena menggunakan desain studi randomized controlled trial (RCT). 2 bukti lainnya memiliki level of evidence 3 karena menggunakan desain studi quasi experiment. IHE dapat dilakukan secara rutin oleh lansia dengan hipertensi di Panti ini. Hal tersebut dilakukan sebagai upaya untuk mengendalikan hipertensi dan diperlukan jadwal bersama agar semua lansia dapat teratur melakukan IHE ini. Keuntungan melakukan IHE dalam waktu yang pendek secara kontinyu selama 2 menit dapat menyebabkan tekanan darah dan denyut jantung mencapai nilai yang stabil, tidak berisiko terjadi cedera, dan teknik yang dilakukan cukup mudah. IHE dapat dilakukan di mana saja, dan hanya memerlukan alat sederhana seperti menggunakan alat berbentuk bola dengan konsistensi kenyal agar bisa ditekan-tekan oleh lansia dengan hipertensi. Bahkan dapat dilakukan tanpa alat sehingga memudahkan penderita hipertensi untuk melakukan IHE tersebut. 


\section{PENDAHULUAN}

Kota Bandung merupakan kota dengan angka prevalensi penyakit hipertensi yang mengalami peningkatan. Pada tahun 2014 tercatat sebanyak 69.328, tahun 2015 sebanyak 71.506, dan tahun 2016 menjadi 84.162. Hipertensi pada lansia angka paling besar ada pada umur 45 sampai 60 tahun yaitu $38,8 \%$, sedangkan pada umur $>60$ tahun relatif lebih sedikit yaitu 25\% (Dinas Kesehatan Kota Bandung, 2019). Kasus lanjut usia (lansia) dengan hipertensi sebanyak 20 dari total 35 lansia yang terbina di Panti Wredha Muhammadiyah Rancabolang Kota Bandung. Dari 20 lansia tersebut 10 lansia terkontrol rutin ke Pusat Kesehatan Masyarakat (Puskemas) untuk berobat, sedangkan sisanya mengobati sendiri. Lansia mengobati sendiri dengan toga ataupun dengan membeli obat darah tinggi sendiri tanpa kontrol ke puskesmas ataupun klinik dan rumah sakit.

Angka kejadian hipertensi yang ada di Kota Bandung dan terutama pada lansia di Panti Wredha Muhammadiyah Rancabolang yang tinggi diperlukan upaya untuk mengendalikan hipertensi tersebut. Berbagai upaya perlu dilakukan untuk mengendalikan angka kejadian hipertensi sehingga dapat menekan angka hipertensi dan salahsatunya yaitu dengan isometric handgrip exercise (IHE). Keuntungan melakukan IHE dalam waktu yang pendek secara kontinyu selama 2 menit menyebabkan tekanan darah dan denyut jantung mencapai nilai yang stabil, tidak berisiko cedera, teknik yang dilakukan cukup sederhana, dapat dilakukan dimana saja dan hanya memerlukan alat sederhana atau bahkan tanpa alat, sehingga memudahkan penderita hipertensi untuk melakukan IHE tersebut.

Lanjut usia yang selanjutnya disingkat lansia merupakan proses yang akan dijalani setiap orang, sebuah proses yang masuk ke dalam continum of care (CoC). CoC meliputi ibu hamil, ibu bersalin, ibu menyusui, bayi balita, anak sekolah sampai lanjut usia. Pengertian lansia menurut para ahli memiliki batasan umur yang beragam, dan yang termasuk lansia adalah individu yang telah mencapai usia 65 tahun keatas dan terbagi ke dalam 3 katagori yaitu Young old 65-74 tahun, Middle old 75-84 tahun, Old old lebih dari 85 tahun. Setiap orang menua dengan cara yang berbeda-beda, berdasarkan waktu dan riwayat hidupnya. Setiap lansia adalah unik, oleh karena itu perawat harus memberikan pendekatan antara satu lansia dengan lansia lainnya (Perry \& Potter, 2009). Lansia adalah keadaan yang ditandai akan kegagalan untuk mempertahankan keseimbangan terhadap stres fisiologis. Salah satu penurunan fungsi tubuh adalah berkurang nya daya tahan tubuh dan mulai kelemahan-kelemahan serta fungsi tubuh mulai berkurang ditandai dengan munculnya penyakit-penyakit degeneratif seperti penyakit tidak menular. Saat ini angka penderita penyakit tidak menular banyak melebihi angka penderita penyakit menular (Effendi \& Makhfudli, 2009).

Berbagai upaya telah ditempuh pemerintah dalam penatalaksanaan hipertensi melalui peluncuran program Penyakit Tidak Menular (PTM) dan Program Pengelolaan Penyakit Kronis (Prolanis). Program PTM menitikberatkan pada upaya preventif dan deteksi dini, sedangkan Prolanis lebih pada upaya kuratif. Penatalaksanaan yang telah dilakukan pada penderita hipertensi dilaksanakan secara konprehensif, meliputi terapi farmakologi dan non farmakologi. Terapi farmakologi, yakni menggunakan obat-obatan antihipertensi, seperti: diuretik, betha-blocker, angiotensin converting enzyme inhibitor (ACE-I)), angiotensin receptor blocker (ARB), direct renin inhibitor, calcium channel blocker (CCB), dan alpha-blocker. Sedangkan terapi nonfarmakologi melalui pembatasan asupan garam, modifikasi diet, penurunan berat badan, dan olahraga rutin (Susilo \& Wulandari, 2011; Ekawati, 2017).

Terapi non farmakologi lebih disarankan dilakukan karena lebih aman untuk tubuh karena tidak mengandung zat-zat kimia yang mempunyai efek negatif juga. Karena obat-obat farmakologi selain fungsi positif nya ada samping obat yang akan muncul. Seperti obat calsium channel blocker contoh amlodipin, clevidipine, dll adalah kulit merah, ruam, melepuh, kesulitan bernafas, pusing, pingsan, detak jantung lambat. Terapi non farmakologi lebih disarankan untuk lansia karena fungsi untuk menetralisir obat dan mengurangi efek samping obat. Terapi non farmakologi ada banyak pilihan dengan obat herbal, modifikasi diet, olahraga rutin (Ekawati, 2017). Olahraga merupakan terapi nonfarmakologi yang telah dilakukan untuk penderita hipertensi karena dapat menurunkan tekanan darah melalui penurunan tahanan perifer yang sistemik yang dihubungkan dengan peningkatan diameter pembuluh darah yang terjadi akibat adaptasi yang 
lama terhadap aktifitas fisik sehingga terjadi vasodilatasi. Sedangkan hasil penelitian dari American Heart Association dalam sebuah studinya menyebut bahwa IHE dapat menjadi alternatif terapi non-farmakologi pada penderita hipertensi (Sukarmin et al., 2013; Nuraini, 2015).

IHE adalah bentuk olahraga statis yang mengontraksikan otot dan menghasilkan tahanan tanpa perubahan panjang otot dan tanpa gerakan sendi melalui gerakan menggenggam (Kisner \& Colby, 2007). IHE ini dapat meningkatkan cardiac output dan denyut nadi sebagai akibat dari kontraksi, sedangkan penurunan tekanan darah didapatkan sebagai respon adaptasi pada saat relaksasi (McGowan \& Mary, 2001), juga dapat menurunkan tekanan darah secara alami dan tanpa obat. IHE ini telah menunjukan pengurangan tekanan darah istirahat (Baross et al., 2013), sehingga dapat disimpulkan bahwa IHE dapat menurunkan tekanan darah dan sangat dianjurkan dilakukan pada usia 35 sampai 55 tahun (Parlindungan et al., 2016).

Manfaat dari IHE lainnya yaitu untuk meningkatkan otot dalam jumlah besar, meningkatkan kekuatan tubuh bagian atas maupun bawah, serta dapat meningkatkan kepadatan tulang. Perubahan yang sangat bermanfaat bagi lansia yaitu dapat membuat lebih aktif dan dapat meningkatkan kualitas hidup. IHE dapat dikombinasikan dengan olahraga jenis lainnya yang dinamis bagi lansia yang mengalami hipertensi dan menjadi bagian dari perawatan yang komprehensif. Berdasarkan uraian di atas, peneliti ingin melakukan systematic review mengenai pengaruh IHE pada lansia yang mengalami hipertensi agar dapat diaplikasikan sebagai evidence-based practice (EBP) pada lansia dengan hipertensi di Panti Wredha Muhammadiyah Rancabolang Kota Bandung.

\section{BAHAN DAN METODE}

Pada penelitian ini menggunakan metode Critical Appraisal Skills Programme (CASP) Systematic Review (CASP, 2018). Metode CASP ini terdiri atas daftar periksa yang terdiri dari 11 pertanyaan untuk membantu memahami sebuah tinjauan sistematis pada sebuah artikel penelitian yang telah dipublikasikan pada sebuah jurnal tertentu yang terindeksi pada PubMed dan Google Scholar (GS).
Daftar periksa tersebut terbagi menjadi 3 bagian yang dipertimbangkan saat penilaian sebagai berikut:

Bagian A: Apakah hasil studi tersebut valid?

Bagian B: Apa hasilnya?

Bagian C: Hasilnya membantu secara lokal?. Daftar periksa yang terdiri atas 11 pertanyaan dirancang untuk membantu memikirkan tentang sebuah permasalahan secara sistematis. Catat jawaban daftar pertanyaan sesuai dengan jawaban di tempat yang tersedia. Apabila ada beberapa pertanyaan bersifat tumpang tindih di antara pertanyaan, maka diminta mencatat 'ya', 'tidak' atau 'tidak dilaporkan'.

Pembuatan daftar periksa tersebut dibuat dengan pembuatan rumusan pertanyaan klinis dengan menggunakan format PICOT. Rumusan PICOT digunakan untuk membantu mengidentifikasi masalah pada satu populasi serta intervensi yang akan dilakukan sehingga proses pencarian bukti atau hasil penelitian lebih spesifik berdasarkan tujuan yang akan dicapai. Adapun penjelasan rumusan PICOT terdiri atas: $\mathbf{P}$ merujuk pada populasi atau pasien; I adalah intervensi yang akan dilaksanakan (fokus utama); $\mathbf{C}$ adalah intervensi pembanding; $\mathbf{O}$ merupakan hasil yang diharapkan; dan $\mathbf{T}$ adalah durasi waktu (dimana $\mathrm{T}$ tidak wajib ada) (Melnyk \& Fineout-Overholt, 2006; Melnyk \& Fineout-Overholt, 2019). Rumusan daftar pertanyaan berdasarkan PICOT dibuat sesuai template pada gambar 1 .

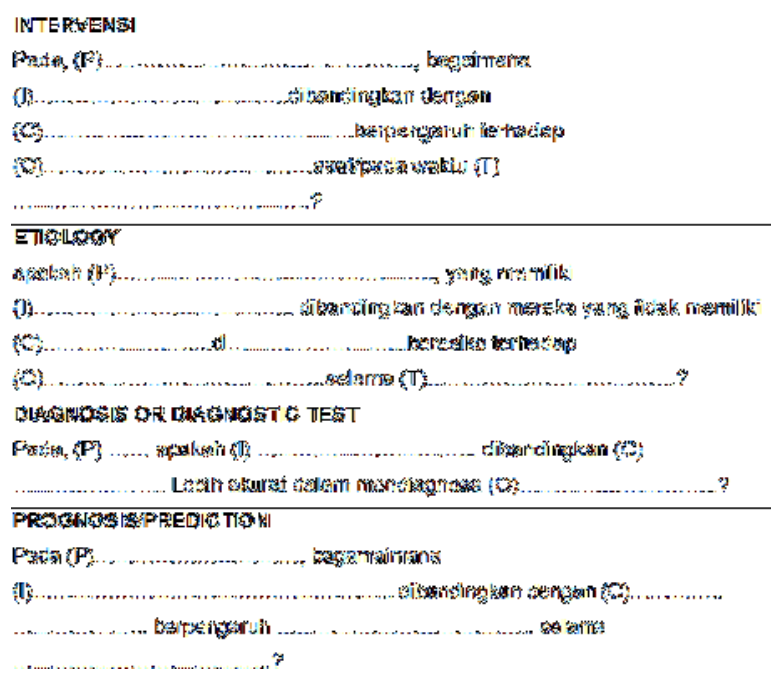

Gambar 1. Template pedoman EBP

Sumber: Melnyk \& Fineout-Overholt, 2006. 
HASIL

Hasil dari rumusan pertanyaan klinis sesuai format PICOT untuk mencari bukti atau hasil penelitian lebih spesifik terkait dengan IHE pada lansia dengan hipertensi sesuai pedoman EBP dijelaskan pada deskripsi sesuai tabel 1 di bawah ini. Dalam pencarian EBP pada penelitian ini menggunakan sumber/database yang paling sering digunakan untuk mencari sumber atau hasil penelitian terbaru melalui situs PubMed dengan alamat https://www.ncbi.nlm.nih.gov/pubmed/ dan Google Scholar dengan alamat website https://scholar.google.co.id/.

Tabel 1. Hasil rumusan PICOT untuk IHE pada lansia dengan hipertensi

\begin{tabular}{|c|c|}
\hline Elemen & Hasil \\
\hline Intervensi & $\begin{array}{l}\text { P: lansia dengan hipertensi } \\
\text { I: isometric handgrip exercise } \\
\text { (IHE) } \\
\text { C: tanpa IHE } \\
\text { O: menurunkan tekanan darah } \\
\text { T: selama } 1 x \text { pelaksanaan IHE } \\
\text { secara berkelompok }\end{array}$ \\
\hline Etiologi & $\begin{array}{l}\text { Apakah lansia dengan } \\
\text { hipertensi yang melakukan IHE } \\
\text { mempengaruhi penurunan } \\
\text { tekanan darah selama } 1 x \\
\text { pelaksanaan terapi aktifitas } \\
\text { kelompok }\end{array}$ \\
\hline Diagnosis & $\begin{array}{l}\text { Pada intervensi keperawatan } \\
\text { lansia dengan hipertensi } \\
\text { apakah IHE efektif dalam } \\
\text { menurunkan tekanan darah }\end{array}$ \\
\hline Prognosis & $\begin{array}{l}\text { Pada lansia dengan hipertensi } \\
\text { keperawatan dengan IHE } \\
\text { selama } 1 x \text { pelaksanaan terapi } \\
\text { dapat berpengaruh pada } \\
\text { penurunan tekanan darah }\end{array}$ \\
\hline
\end{tabular}

Sumber: hasil elaborasi penelitian, 2020.

Dalam tahapan proses pencarian reference memperhatikan penggunaan strategi pencarian tepat dan efektif yaitu dengan memasukan PICOT secara lengkap kedalam pencarian dan menggunakan sinonim untuk setiap istilah atau kata kunci, serta menggunakan menggunakan advance search dengan pemakain boolen operator (AND/OR) dan mengunduh (download) hasil penelitian tersebut untuk mendapatkan artikelnya secara penuh (fulltext). Pencarian EBP tersebut digambarkan pada gambar 2 di bawah ini.

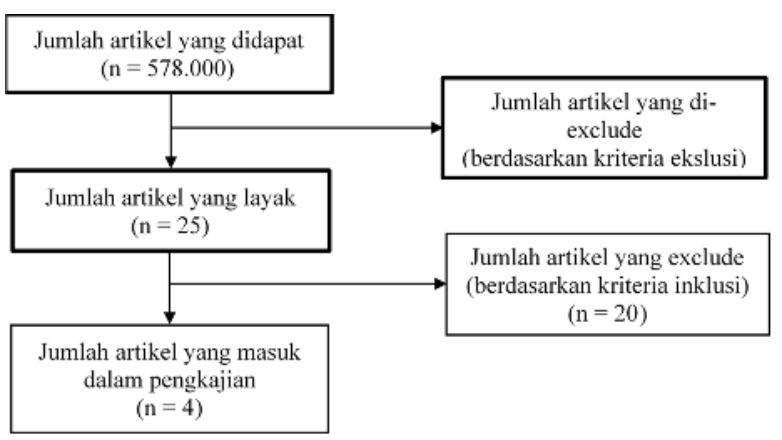

Gambar 2. Diagram alir proses pencarian EBP Sumber: hasil elaborasi peneliti, 2020.

Penentuan kriteria inklusi dan ekslusi diperlukan untuk melakukan filtrasi terhadap pencarian sehingga hasil pencarian lebih efektif. Selanjutnya dilakukan skrining terhadap hasil-hasil studi yang telah ada dari proses pencarian sesuai dengan kriteria dan tujuan yang ingin dicapai dan menentukan berapa jumlah arikel yang sesuai dengan kriteria inklusi dan ekslusi yang telah ditetapkan agar dapat ditetapkan artikel yang tepat yang akan dijadikan bukti ilmiah pelaksaan EBP. Strategi yang digunakan yaitu memasukan kata lanjut usia/lansia (elderly), hipertensi (hypertension) dan isometric handgrip exercise (IHE). Hasil pencarian tersebut diperoleh dan dijelaskan pada tabel 2 di bawah ini.

Tabel 2. Hasil riwayat pencarian EBP untuk IHE pada lansia dengan hipertensi

\begin{tabular}{lcc}
\hline \multicolumn{1}{c}{ Query } & $\begin{array}{c}\text { Jumlah yang } \\
\text { ditemukan }\end{array}$ & Waktu \\
\hline Sumber: PubMed dan GS & \\
\hline Elderly & 5149571 & $2: 25: 40$ \\
\hline Hypertension & 16236 & $2: 25: 57$ \\
\hline Handgrip Exercise & 25 & $2: 26: 12$ \\
\hline Sumber: hasil elaborasi penelitian, 2020.
\end{tabular}


Penilaian terhadap hasil penelitian atau bukti yang diperoleh diperlukan untuk menentukan apakah hasil penelitian tersebut merupakan hasil penelitian terbaik yang tidak menimbulkan bahaya jika diterapkan, dan diperoleh hasil akhir sebanyak 4 artikel yang memenuhi kriteria yang ditetapkan sesuai dengan tujuan penelitian ini. Langkah pada tahap ini menjadi tahapan kritis terhadap artikel yang didapatkan untuk kemudian dinilai sesuai dengan format analisis Daftar periksa CASP Systematic Review Checklist dari artikel yang diperoleh. 11 daftar periksa tersebut terdapat pada tabel 3 di bawah ini.

Tabel 3. CASP Checklist IHE terhadap penurunan tekanan darah

\begin{tabular}{ll}
\hline \multicolumn{1}{c}{ Pertanyaan } & \multicolumn{1}{c}{ Fokus } \\
\hline Apakah studi & - Studi populasi \\
tersebut & - Intervensi yang \\
menjelaskan & diberikan \\
masalahnya secara & - Kelopok control \\
fokus & (komparasi) \\
& - Hasil (outcome) \\
\hline Apakah pembagian & - Bagaimana ini \\
pasien kedalam & dilakukan \\
kelompok intervensi & - Apakah alokasi \\
dan kontrol & pasien dilakukan \\
dilakukan secara & secara \\
acak & tersembunyi dari \\
& peneliti dan pasien \\
\hline Apakah semua & - Apakah dihentikan \\
pasien & lebih awal \\
yang terlibat dalam & - Apakah pasien \\
penelitian & dianalisis dalam \\
dicatat dengan & kelompok untuk \\
benar di & yang diacak \\
kesimpulannya & \\
\hline Apakah pasien, & \\
petugas kesehatan \\
dan responden pada \\
penelitian ini 'Blind’
\end{tabular}

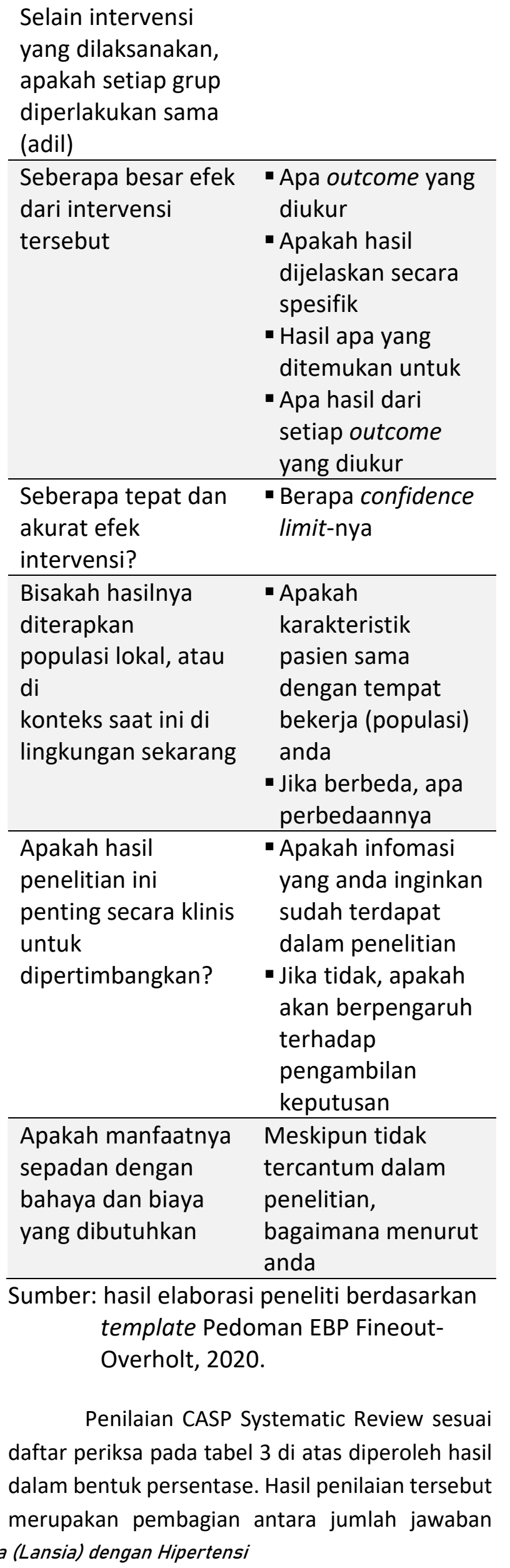

Selain intervensi

yang dilaksanakan, apakah setiap grup diperlakukan sama (adil)

Apa outcome yang

- Apakah hasil dijelaskan secara ditemukan untuk

Apa hasil dari setiap outcome yang diukur

Seberapa tepat dan confidence akurat efek (1)

Bisak 
'ya' yang memiliki nilai 1 dibagi dengan jumlah pertanyaan pada kolom fokus pada 11 daftar pertanyaan CASP Systematic Review, seperti yang dijelaskan pada tabel 4 di bawah ini.

\section{Tabel 4. Hasil penilaian CASP Checklist}

\begin{tabular}{|c|c|}
\hline udul Artikel & Hasil \\
\hline $\begin{array}{l}\text { The effect of slow-loaded breathing } \\
\text { training on the blood pressure } \\
\text { response to handgrip exercise in } \\
\text { patients with isolated systolic } \\
\text { hypertension }\end{array}$ & $95 \%$ \\
\hline $\begin{array}{l}\text { Low intensity isometric handgrip } \\
\text { exercise has no transient effect on } \\
\text { blood pressure in patients with } \\
\text { coronaryartery disease }\end{array}$ & $73 \%$ \\
\hline $\begin{array}{l}\text { Efektivitas Isometric } \text { Handgrip } \\
\text { Exercise dan Slow Deep Breathing } \\
\text { Exercise Terhadap Perubahan } \\
\text { Tekanan Darah pada Penderita } \\
\text { Hipertensi }\end{array}$ & $59 \%$ \\
\hline $\begin{array}{l}\text { Latihan Isometrik Bermanfaat } \\
\text { Menurunkan Tekanan Darah Pada } \\
\text { Penderita Hipertensi }\end{array}$ & 77 \\
\hline
\end{tabular}

Sumber: hasil elaborasi peneliti, 2020.
Hasil penilaian kemudian disesuaikan dengan level of evidence yang tingkatannya dijelaskan pada gambar 3. Rekapitulasi hasil penilaian kualitas bukti dengan CASP Systematic Review Checklist dan Level of Evidence dijelaskan pada tabel 5.

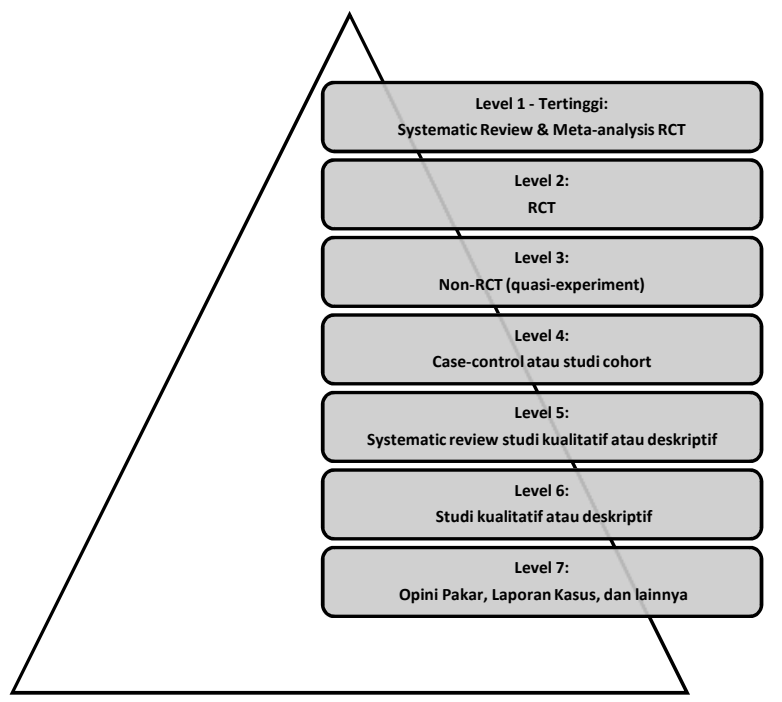

Gambar 3. Level of Evidence Sumber: hasil elaborasi peneliti (2020)

Tabel 5. Rekapitulasi penilaian kualitas bukti CASP Checklist dan Evidence Level

\begin{tabular}{|c|c|c|c|c|c|c|c|}
\hline Penulis & Lokasi & Metode & $\begin{array}{l}\text { Populasi } \\
\text { \& Sampel }\end{array}$ & Instrumen & Hasil & $\begin{array}{l}\text { Nilai } \\
\text { CASP }\end{array}$ & $\begin{array}{c}\text { Evidence } \\
\text { Level }\end{array}$ \\
\hline $\begin{array}{l}\text { Ubolsakka- } \\
\text { Jones, C., } \\
\text { Sangthong, } \\
\text { B., } \\
\text { Khrisanapant, } \\
\text { W., \& Jones, } \\
\text { D.A. (2017) }\end{array}$ & Thailand & $\begin{array}{l}\text { Prospective } \\
\text { randomized } \\
\text { trial }\end{array}$ & $\begin{array}{l}30 \text { orang } \\
\text { terbagi } \\
\text { menjadi } 3 \\
\text { kelompok }\end{array}$ & $\begin{array}{l}\text { Pernafasan } \\
\text { dalam dan } \\
\text { isometric } \\
\text { handgrip } \\
\text { exercise }\end{array}$ & $\begin{array}{l}\text { Hasil } \\
\text { menunjukkan } \\
\text { bahwa } \\
\text { pengobatan } \\
\text { konvensional } \\
\text { pada pasien } \\
\text { yang lebih tua } \\
\text { dengan isolated } \\
\text { systolic } \\
\text { hypertension } \\
\text { (ISH) dapat } \\
\text { ditingkatkan } \\
\text { dengan dua cara } \\
\text { dengan latihan } \\
\text { pernapasan } \\
\text { lambat: istirahat } \\
\text { systolic blood } \\
\text { pressure (sBP) } \\
\text { dapat dikurangi } \\
\text { sampai } 10\end{array}$ & $95 \%$ & Level 2 \\
\hline
\end{tabular}




\begin{tabular}{|c|c|c|c|c|c|c|c|}
\hline & & & & & $\begin{array}{l}\text { mmHg, lebih dari } \\
\text { yang dapat } \\
\text { dicapai oleh } \\
\text { terapi } \\
\text { farmakologis } \\
\text { konvensional, } \\
\text { sedangkan } \\
\text { respon terhadap } \\
\text { latihan statis } \\
\text { mungkin } \\
\text { berkurang } \\
\text { sekitar dua kali } \\
\text { nilai ini. }\end{array}$ & & \\
\hline $\begin{array}{l}\text { Goessler, K., } \\
\text { Buys, R., \& } \\
\text { Cornelissen, } \\
\text { V. (2016) }\end{array}$ & Belgia & $\begin{array}{l}\text { Randomized } \\
\text { controlled } \\
\text { cross-over }\end{array}$ & $\begin{array}{l}21 \text { orang } \\
\text { melakukan } \\
\text { dua sesi } \\
\text { percobaan }\end{array}$ & $\begin{array}{l}\text { isometric } \\
\text { handgrip } \\
\text { exercise }\end{array}$ & $\begin{array}{l}\text { Hasil kami } \\
\text { menunjukkan } \\
\text { bahwa latihan } \\
\text { isometrik } \\
\text { handgrip yang } \\
\text { dilakukan pada } \\
\text { intensitas } \\
\text { rendah aman } \\
\text { pada pasien } \\
\text { dengan coronary } \\
\text { artery disease } \\
\text { (CAD) tetapi } \\
\text { tidak } \\
\text { menginduksi } \\
\text { penurunan BP } \\
\text { sementara. }\end{array}$ & $72,7 \%$ & Level 2 \\
\hline $\begin{array}{l}\text { Andri, J., } \\
\text { Waluyo, A., } \\
\text { Jumaiyah, } \\
\text { W., \& } \\
\text { Nastashia, D. } \\
\text { (2018) }\end{array}$ & $\begin{array}{l}\text { Bengkulu, } \\
\text { Indonesia }\end{array}$ & $\begin{array}{l}\text { Quasi } \\
\text { ekperimental }\end{array}$ & $\begin{array}{l}32 \text { orang } \\
\text { terbagi } \\
\text { kedalam } 2 \\
\text { kelompok } \\
\text { kontrol dan } \\
\text { eksperimen }\end{array}$ & $\begin{array}{l}\text { Isometric } \\
\text { handgrip } \\
\text { exercise dan } \\
\text { slow deep } \\
\text { breathing }\end{array}$ & $\begin{array}{l}\text { Hasil kami } \\
\text { menunjukkan } \\
\text { bahwa baik } \\
\text { isometric } \\
\text { handgrip } \\
\text { exercise maupun } \\
\text { slow deep } \\
\text { breathing } \\
\text { exercise dapat } \\
\text { menurunkan } \\
\text { tekanan darah } \\
\text { sistolik dan } \\
\text { diastolik secara } \\
\text { bermakna pada } \\
\text { pasien } \\
\text { hipertensi. }\end{array}$ & $59 \%$ & Level 3 \\
\hline $\begin{array}{l}\text { Parlindungan, } \\
\text { T., Lukitasari, } \\
\text { A., \& } \\
\text { Mudatsir. } \\
\text { (2016) }\end{array}$ & $\begin{array}{l}\text { Aceh, } \\
\text { Indonesia }\end{array}$ & $\begin{array}{l}\text { Quasi } \\
\text { ekperimental }\end{array}$ & $\begin{array}{l}37 \text { orang } \\
\text { sebagai } \\
\text { kelompok } \\
\text { kontrol dan } \\
37 \text { orang } \\
\text { sebagai } \\
\text { kelompok } \\
\text { intervensi }\end{array}$ & $\begin{array}{l}\text { Isometric } \\
\text { exercise }\end{array}$ & $\begin{array}{l}\text { Hasil penelitian } \\
\text { menunjukkan } \\
\text { ada pengaruh } \\
\text { isometric } \\
\text { exercise } \\
\text { terhadap } \\
\text { penurunan } \\
\text { tekanan darah } \\
\text { pada penderita } \\
\text { hipertensi, baik } \\
\text { dilakukan sendiri } \\
\text { maupun }\end{array}$ & $77 \%$ & Level 3 \\
\hline
\end{tabular}




\author{
kombinasi \\ dengan olahraga \\ yang dinamis \\ sebagai bagian \\ dari rejimen \\ perawatan yang \\ komprehensif.
}

Sumber: hasil elaborasi peneliti, 2020.

\section{PEMBAHASAN}

Hasil penelitian pada bukti pertama yaitu menggunakan desain studi prospective randomized trial yang dilakukan di Srinagarind pada tiga rumah sakit komunitas di Provinsi Khon Kaen, Thailand. Kriteria inklusi adalah diagnosis ISH ringan hingga sedang, usia pasien di atas 60 tahun dan konstan pengobatan minimal 1 bulan sebelum penelitian. Tiga puluh lima pasien diskrining dan 5 dikeluarkan; 30 sisanya dibagi menjadi tiga kelompok, dan hasil dari dua kelompok merupakan kelompok pelatihan pernafasan dan satu kelompok kontrol. Kriteria ekslusi adalah pasien yang rutin berolahraga atau menderita penyakit kardiovaskular aktif, stroke, gagal ginjal kronis dan penyakit pernapasan kronis (PPOK). Pembagian kelompok secara acak, ada kelompok dengan terapi pernafasan dilakukan intervensi setiap hari selama 30 menit selama 8 mingggu. Sedangkan pada kelompok dengan melakukan IHE selama 2 menit selama 2 minggu. Keseimpulan dari penelitian tersebut adalah IHE dapat menurunkan tekanan darah 20 $\mathrm{mmHg}$ lebih dari yang dicapai terapi farmakologi (Ubolsakka-Jones et al., 2017).

Hasil penelitian pada bukti kedua yaitu menggunakan desain studi randomized controlled cross-over dengan 21 pasien laki-laki (usia rata-rata 68 tahun dengan kisaran 55-70) dengan penyakit jantung koroner yang stabil, dalam pengobatan penyakit arteri yang berpartisipasi dalam program rehabilitasi jantung fase III dimasukkan dalam penelitian ini. Semua pasien menyelesaikan 2 sesi eksperimen secara acak yaitu satu sesi kontrol dan satu sesi IHE intensitas rendah. Tekanan darah diukur dengan menggunakan monitor tekanan darah rawat jalan 24 jam pra-intervensi, selama satu jam di kantor dan selanjutnya selama 24 jam selama mereka latihan rutin sehari-hari. Hasil menunjukan bahwa IHE yang dilakukan pada intensitas rendah aman pada pasien dengan penyakit CAD tetapi tidak menginduksi penurunan tekanan darah (Goessler et al., 2016).

Hasil penelitian pada bukti ketiga yaitu menggunakan desain quasi eksperiment dengan rancangan penelitian two group pretest postest pada 32 responden. Peneltian bertujuan untuk mengidentifikasi efektifitas IHE dan slow deep breathing exercise (SDB) terhadap perubahan tekanan darah pada penderita hipertensi. Partisipan yang telah setuju untuk dijadikan responden mengisi dan menandatangani informed concent dan mengisi seluruh kuesioner yang diberikan dengan jujur. Kemudian peneliti melakukan kunjungan ke rumah responden. Responden dibagi kedalam dua kelompok, pada kelompok intervensi IHE dilakukan selama lima hari dimana pengukuran tekanan darah dilakukan pada awal dan setelah intervensi pada hari ke 5, sedangkan pada kelompok SDB dilakukan selama 4 hari dimana pengukuran tekanan darah dilakukan pada awal dan setelah intervensi pada hari ke 4.

Intervensi dilakukan secara individual dan intervensi dilakukan oleh pasien setelah diajarkan oleh peneliti dan diimplementasikan pada kelompok intervensi IHE dan SDB. Pada kelompok intervensi IHE diberikan selama 5 hari berturut-turut dengan frekuensi 1 kali sehari dengan bantuan handgrip. Jumlah total durasi selama IHE sebanyak 180 detik atau 3 menit dan pengukuran tekanan darah setelah intervensi dilakukan setelah istirahat 5 menit. Sedangkan kelompok SDB diberikan selama 4 hari dengan frekuensi 2 kali sehari, responden dapat melakukan 13 kali SDB 6 kali per menit dengan istirahat 10 detik selama 15 menit yang diberikan. Kesimpulan yang didapat dari jurnal adalah Intervensi isometric handgrip exercise 
dan slow deep breathing exercise yang diberikan pada penelitian ini efektif dalam menurunkan tekanan darah pada pasien hipertensi (Andri et al., 2018).

Hasil penelitian pada bukti keempat yaitu menggunakan desain quasi eksperiment dengan rancangan nonrandom with control pretest postest. Rancangan ini terdiri dari 2 kelompok, yaitu kelompok intervensi dan kelompok kontrol. Pada kelompok perlakuan diberikan penerapan IHE sedangkan kelompok kontrol tidak diberikan, tetapi keduanya tetap diberikan pretest dan postest. Tehnik pengambilan sampel dalam penelitian ini dengan menggunakan purposive sampling atau judgmental sampling yaitu memilih subjek berdasarkan kriteria dan pertimbangan pribadi peneliti. Jumlah sampel sebanyak 37 responden untuk kelompok kontrol dan 37 responden kelompok perlakuan. Penelitian ini telah dilaksanakan pada tanggal 21 September sampai 20 November 2015 di Kecamatan Banda Sakti Kota Lhokseumawe.

IHE dilakukan 3 kali dalam seminggu selama 9 minggu. Hasil penelitian menunjukkan ada pengaruh IHE terhadap penurunan tekanan darah pada penderita hipertensi. Dengan demikian sangat dianjurkan pada penderita hipertensi dengan menggunakan IHE untuk menurunkan tekanan darah baik dilakukan sendiri maupun kombinasi dengan olahraga yang dinamis sebagai bagian dari rejimen perawatan yang komprehensif. IHE sangat baik pada usia 35 sampai 55 tahun karena pada usia tersebut lebih berisiko mengalami hipertensi sehingga dapat mempertahankan tekanan darah secara mandiri dan terkontrol (Parlindungan et al., 2016).

Dari keempat bukti hasil penelitian tersebut di atas dapat ditarik kesimpulan bahwa IHE dapat menurunkan tekanan darah pada pasien hipertensi. IHE sebaiknya dilakukan secara rutin dengan kisaran waktu pelaksanaan 5 sampai 30 menit dan diselingi istirahat agar peredaran darah lancar. IHE ini dapat meningkatkan cardiac output dan denyut nadi sebagai akibat dari kontraksi, sedangkan penurunan tekanan darah didapatkan sebagai respon adaptasi pada saat relaksasi. IHE dapat menurunkan tekanan darah secara alami, American Heart Association dan Hypertension Canada dalam sebuah studinya menuliskan keuntungan melakukan IHE dalam waktu yang pendek secara kontinyu selama 2 menit menyebabkan tekanan darah dan denyut jantung mencapai nilai yang stabil, tidak berisiko terjadi cedera, tehnik yang dilakukan sederhana dan bisa dilakukan dimana saja, serta hanya memerlukan alat sederhana atau bahkan tanpa alat, sehingga memudahkan penderita hipertensi (Carlson et al., 2016).

IHE merupakan bentuk statis yang terjadi bila otot berkontraksi tanpa adanya perubahan pada panjang otot atau pergerakan sendi yang terlihat yang dapat dilakukan di mana saja dengan intensitas dari ringan ke sedang. IHE dapat menurunkan reaktivitas kardiovaskuler terhadap stresor psikofisiologis pada orang dengan tekanan darah tinggi (Badrov et al., 2013). Penelitian sebelumnya yang dilakukan pada responden yang mengalami hipertensi juga menjelaskan bahwa pasien yang diberikan IHE selama 5 hari berturut-turut memperlihatkan penurunan tekanan darah sistolik dan diastolik yang bermakna antara sebelum dan setelah diberikan intervensi (Sabar, 2015).

\section{KESIMPULAN DAN SARAN}

Isometric handgrip exercise (IHE) dapat dilakukan secara rutin oleh lansia dengan hipertensi di Panti Wredha Muhammadiyah Rancabolang Kota Bandung. Hal tersebut dilakukan sebagai upaya untuk mengendalikan hipertensi. Perlu ada nya jadwal bersama agar semua lansia dapat teratur melakukan IHE ini. Keuntungan melakukan IHE dalam waktu yang pendek secara kontinyu selama 2 menit dapat menyebabkan tekanan darah dan denyut jantung mencapai nilai yang stabil, tidak berisiko cedera, teknik yang dilakukan cukup sederhana. IHE dapat dilakukan dimana saja dan hanya memerlukan alat sederhana seperti menggunakan alat bola dengan konsistensi kenyal agar bisa di tekan-tekan oleh lansia dengan hipertensi, atau bahkan tanpa alat 
sehingga memudahkan penderita hipertensi untuk melakukan IHE tersebut.

Berdasarkan penelitian ini dan untuk meningkatkan kemampuan klinik perawat di ruangan, disarankan agar penelitian ini dapat diaplikasikan bagi pasien dengan hipertensi untuk membantu menururnkan tekanan darah secara efektif dan efisien, sehingga tekanan darah dapat terkontrol dan gejala-gejala stroke dapat dicegah dan dihindari, kesehatan lansia yang mandiri produktif dapat tercapai, serta angka harapan hidup pada lansia juga meningkat apabila PTM dapat dikendalikan dan terkontrol. Dan bagi peneliti, mahasiswa dan praktisi keperawatan diharapkan intervensi IHE ini dapat dilaksanakan dengan baik. Hasil penelitian ini pun dapat dijadikan bahan pelajaran bagi mahasiswa yang praktek di lapangan tempat dilakukan intervensi tersebut.

\section{UCAPAN TERIMA KASIH}

Ucapan terima kasih kepada Dr. Arif Susanto, M.M.Kes., M.Si., MBA. yang memberikan bantuan dana, dukungan serta memberikan kontribusi berupa saran dan masukan dalam penyusunan laporan penelitian ini.

\section{DAFTAR PUSTAKA}

Andri, J., Waluyo, A., Jumaiyah, W., \& Nastashia, D. (2018). Efektivitas Isometric Handgrip Exercise dan Slow Deep Breathing Exercise terhadap Perubahan Tekanan Darah pada Penderita Hipertensi. Jurnal Keperawatan Silampari, 2 (1): 371-384.

Badrov, M.B., Horton, S., Millar, P.J., \& McGowan C.L. (2013). Cardiovascular Stress Reactivity Tasks Successfully Predict the Hypotensive Response of Isometric Handgrip Training in Hypertensives. Psychophysiology, 50 (4): 407-414.

Baross, A.W., Willes, J.D., \& Swaine, I.L. (2013). Double-leg Isometric Exercise Training in
Older Men. Journal of Sport Medicine, 4: 3340.

Carlson, G.A., Danzig, P.A., Dougherty, L.R., Bufferd, S.J., \& Klein, D.N. (2016). Loss of Temper and Irritability: the Relationship to Tantrums in a Community and Clinical Sampel. Journal of Child and Adolescent Psychopharmacology, 26 (2): 114-122.

Critical Appraisal Skills Programme. (2018). CASP Systematic Review Checklist. https://caspuk.net/wp-

content/uploads/2018/01/CASP-

Systematic-Review-Checklist 2018.pdf

Dinas Kesehatan Kota Bandung. (2019). Profil Kesehatan Kota Bandung. https://dinkes.bandung.go.id/dashboard.p hp?page=profildinas

Effendi, F., \& Makhfudli. (2009). Keperawatan Kesehatan Komunitas: Teori dan Praktek dalam Keperawatan. Salemba Medika: Jakarta.

Ekawati, L.R. (2017). Pengaruh Prolanis terhadap Kolesterol pada Penderita Hipertensi di Puskesmas Banjardawa Kabupaten Pemalang. Skripsi, Universitas Muhammadiyah Semarang.

Goessler, K., Buys, R., \& Cornelissen, V. (2016). Low Intensity Isometric Handgrip Exercise Has No Transient Effect on Blood Pressure in Patients with Coronary Artery Disease. Journal of Hypertension, 34: 350-351.

Kisner, C., \& Colby L.A. (2007). Therapeutic Exercise: Foundations and Techniques. $6^{\text {th }}$ Ed. F.A. Davis Company: Philadelphia.

McGowan, C.L., \& Mary, P. (2001). Menjaga Kebugaran Jantung. Cetakan 1. Jakarta: Raja Grafindo Persada.

Melnyk, B. M., \& Fineout-Overholt, E. (2006). Consumer preferences and values as an integral key to evidence-based practice. Nursing Administration Quarterly, 30, 123127. 
Melnyk, B.M., \& Fineout-Overholt, E. (2011). Evidence-based Practice in Nursing and Healthcare: A Guide to Best Practice. $3^{\text {rd }}$ Ed., Wolters Kluwer: Philadelphia.

Nuraini, B. (2015). Risk Factors of Hypertension. Jurnal Majority, 4 (5): 10-19.

Parlindungan, T., Lukitasari, A., \& Mudatsir. (2016). Latihan Isometrik Bermanfaat Menurunkan Tekanan Darah Pada Penderita Hipertensi. Jurnal IImu Keperawatan, 4 (1): 71-81.

Potter, P.A., \& Perry, A.G. (2009). Fundamental Keperawatan, Ed. 7. Jakarta: Salemba Medika.
Sabar, S. (2015). Pengaruh Isometric Handgrip Exercise terhadap Perubahan Tekanan Darah. Universitas Indonesia: Depok.

Susilo, Y., \& Wulandari, A. (2011). Cara Jitu Mengatasi Hipertensi. Yogyakarta: Andi.

Sukarmin, S., Nurachmah E., \& Gayatri, D. 2013. Penurunan Tekanan Darah pada Pasien Hipertensi melalui Brisk Walking Exercise. Jurnal Keperawatan Indonesia, 16 (1): 3339.

Ubolsakka-Jones, C., Sangthong, B., Khrisanapant, W., \& Jones, D.A. (2017). The Effect of Slowloaded Breathing Training on the Blood Pressure Response to Handgrip Exercise in Patients with Isolated Systolic Hypertension. Hypertension Research, 40: 885-891. 